\title{
Pengaruh Pendapatan Murabahah dan Pendapatan Musyarakah Terhadap Profitabilitas Pada PT. Bank BNI Syariah Periode 2012-2016
}

\author{
${ }^{1}$ Dodi Supriyanto, ${ }^{2}$ Daeng Kusumah \\ ${ }^{1}$ Email : dodi.supriyanto@ekuitas.ac.id \\ ${ }^{1,2}$ STIE Ekuitas, J1. PHH. Mustopa No. 31 Bandung
}

\begin{abstract}
This study aims to determine how the development of murabahah income and musharaka income and its effect on profitability (ROA). Factors tested in this study are murabahah and musyarakah income as independent variables and profitability is the dependent variable. The subject of this study is Bank BNI Syariah.

The research method used in this study is descriptive and verification methods. The population used is secondary data on the financial statements of Bank BNI Syariah for the 2012-2016 period. And the sample is murabahah income, musharaka income and profitability (ROA). This method of analysis is multiple linear regression. At a significance level of 5\%. The program used in analyzing data uses statistical package for social science (SPSS) versus 25.

The results showed that partially obtained murabahah income value of 1.062 with a significance of 0.303 which means that murabahah income (X1) has a positive and influential relationship, but not significant to profitability. Whereas musyarakah income obtained a value of -0.081 with a significant level of 0.936 , which means that musharaka income has a negative but not significant effect on profitability. While murabahah and musyarakah income simultaneously but not significant to profitability (ROA) simultaneously.
\end{abstract}

\section{Keywords : Murabahah, Musyarakah and Profitability (ROA).}

\section{A. PENDAHULUAN}

Dalam praktisi perbankan, kini masyarakat mengetahui bahwa bank syariah memiliki produk-produk yang amat variatif, berbeda dengan bank kovensional yang hanya berfokus pada tabungan, deposito dan penyaluran dana melalui kredit. Bank syariah memiliki banyak produk yang beragam terutama dalam segi pembiayaan yang dikemas dengan skim-skim akad yang berbeda misalnya seperti mudharabah, musyarakah, murabahah, ijarah dan lain-lain.
Menurut Karim (2008:97) Bank syariah yang berfungsi sebagai lembaga intermediasi keuangan, melaksanakan kegiatan operasionalnya dengan menghimpun dana dari masyarakat dan kemudian menyalurkannya kembali kepada masyarakat melalui pembiayaan. Dana yang dihimpun dari masyarakat biasanya disimpan dalam bentuk giro, tabungan dan deposito baik dengan prinsip wadiah maupun prinsip mudharabah. Sedangkan penyaluran dana dilakukan oleh bank syariah melalui pembiayaan dengan empat pola penyaluran yaitu prinsip jual beli, 
prinsip bagi hasil, prinsip ujroh dan akad pelengkap.

Pengelolaan Lembaga keuangan syariah salah satunya menggunakan Profit sharing atau sistem bagi hasil. Profit sharing atau sistem bagi hasil merupakan prinsip utama yang diterapkan dalam Lembaga keuangan syariah kepada nasabahnya. Sistem ini merupakan suatu sistem yang membedakan dengan sistem yang ada di lembaga keuangan konvensional. Dengan telah diberlakukannya UU tentang Perbankan Syariah, maka terdapat 2 (dua) UU yang mengatur lembaga keuangan di Indonesia, yaitu UU No.7 Tahun 1992 tentang lembaga keuangan sebagaimana telah diubah dengan UU No. 10 Tahun 1998, dan UU No. 21 Tahun 2008 tentang lembaga keuangan Syariah.

Praktik pembiayaan yang sebenarnya dijalankan lembaga keuangan syariah adalah pembiayaan dengan sistem bagi hasil atau syirkah. Praktik bagi hasil ini dikemas dalam dua jenis pembiayaan yaitu pembiayaan mudharabah dan pembiayaan musyarakah. Jenis pembiayaan lainnya dikemas dalam pembiayaan berakad atau sistem jual beli yaitu pembiayaan murabahah, ba'i assalam, dan ba'i istishna (Antonio, 2007:156).

Adapun data Statistik Perbankan Syariah di Indonesia tahun 2012-2016 sebagai

berikut:

\section{Tabel 1.1 Komposisi Pembiayaan Bank Umum Syariah dan Unit Usaha Syariah Statistik Perbankan Syariah (Periode 2012-2016)}

(dalam Milyaran Rupiah)

\begin{tabular}{|c|c|c|c|c|c|c|}
\hline \multirow{2}{*}{ Tahun } & \multicolumn{7}{|c|}{ Akad } \\
\cline { 2 - 7 } & Mudharabah & Musyarakah & Murabahah & Istishna & Qard & Ijarah \\
\hline 2012 & 12.027 & 27.667 & 88.665 & 376 & 12.09 & 7.345 \\
\hline 2013 & 13.625 & 39.874 & 110.565 & 582 & 8.995 & 10.481 \\
\hline 2014 & 14.354 & 49.336 & 117.371 & 635 & 5.965 & 11.62 \\
\hline 2015 & 14.82 & 60.713 & 122.111 & 770 & 3.951 & 10.631 \\
\hline 2016 & 15.292 & 78.421 & 139.536 & 878 & 4.731 & 9.15 \\
\hline Jumlah & 70.118 & 256.011 & 578.248 & 3241 & 35.732 & 49.227 \\
\hline
\end{tabular}

\section{Sumber: http://www.ojk.go.id/id (Data diolah)}

Berdasarkan pada Tabel 1.1 dapat dilihat secara umum bahwa posisi pembiayaan murabahah mendominasi pembiayaan perbankan syariah di Indonesia dengan jumlah pembiayaan mencapai Rp.576.248 Milyar dalam 5 tahun terakhir dengan diikuti dengan pembiayaan Musyarakah dengan jumlah pembiayaan mencapai Rp.256.011 Milyar. Hal ini menunjukan bahwa pembiayaan jual beli dengan akad murabahah merupakan pembiayaan yang paling dominan pada perbankan syariah Indonesia.

Data berikut adalah fenomena kinerja keuangan bank dilihat dari sudut pembiayaan dan pendapatan murabahah dan musyarakah serta dari Return On Asset (ROA) pada Bank BNI Syariah. 
Tabel 1.2 Pembiayaan Murabahah, Musyarakah dan ROA pada PT. Bank BNI Syariah Periode 2012-2016

\begin{tabular}{|l|c|c|l|}
\hline Tahun & $\begin{array}{c}\text { Pembiayaan } \\
\text { Murabahah } \\
\text { (Rp Jutaan) }\end{array}$ & $\begin{array}{c}\text { Pembiayaan } \\
\text { Musyarakah } \\
\text { (Rp Jutaan) }\end{array}$ & ROA \\
\hline 2012 & 7.938 .490 & 980.932 & $1.48 \%$ \\
\hline 2013 & 12.873 .768 & 1.110 .727 & $1.37 \%$ \\
\hline 2014 & 18.434 .132 & 1.430 .590 & $1.27 \%$ \\
\hline 2015 & 21.774 .588 & 2.168 .084 & $1.43 \%$ \\
\hline 2016 & 24.980 .801 & 3.012 .748 & $1.44 \%$ \\
\hline
\end{tabular}

Tabel 1.3 Pendapatan Murabahah, Musyarakah dan ROA pada PT. Bank BNI Syariah Periode 2012-2016

\begin{tabular}{|l|c|c|c|}
\hline Tahun & $\begin{array}{c}\text { Pendapatan } \\
\text { Murabahah } \\
\text { (Rp Jutaan) }\end{array}$ & $\begin{array}{c}\text { Pendapatan } \\
\text { Musyarakah } \\
\text { (Rp.Jutaan) }\end{array}$ & ROA \\
\hline 2012 & 527.024 & 106.069 & $1.48 \%$ \\
\hline 2013 & 854.003 & 117.623 & $1.37 \%$ \\
\hline 2014 & 1.440 .710 & 132.648 & $1.27 \%$ \\
\hline 2015 & 1.741 .998 & 155.862 & $1.43 \%$ \\
\hline 2016 & 1.880 .955 & 254.817 & $1.44 \%$ \\
\hline
\end{tabular}

Sumber : https://www.bnisyariah.co.id

Berdasarkan Tabel 1.3 bahwa penilaian kinerja Bank BNI Syariah memiliki ROA fluktuasi yang cenderung menurun. pada tahun 2012 Return On Asset sebesar 1,48\% mengalami penurunan pada tahun 2013 menjadi $1.37 \%$, lalu menurun kembali pada tahun 2014 sebesar 1,27\% sedangkan pada tahun 2015 sebesar $1,43 \%$ meningkat kembali pada tahun 2016 menjadi $1,44 \%$.

Dari Tabel 1.2 terlihat bahwa untuk pendapatan murabahah dan musyarakah mengalami peningkatan setiap tahunnya dan sejalan dengan pembiayaan murabahah dan musyarakah yang setiap tahunnya mengalami peningkatan. Hal tersebut justru berbanding terbalik dengan ROA yang setiap tahunnya fluktuasi dan cenderung menurun. Dilihat dari data yang ada, pada tahun 2012 Return On Asset sebesar $1,48 \%$ mengalami penurunan pada tahun 2013 menjadi $1.37 \%$, lalu menurun kembali pada tahun 2014 sebesar 1,27 \% sedangkan pada tahun 2015 sebesar 1,43\% meningkat kembali pada tahun 2016 menjadi $1,44 \%$ meskipun masih berada dibawah tahun 2012.

\section{B. LANDASAN TEORI \\ Pengertian Pendapatan}

Menurut Harahap (2011:236) :

"pendapatan adalah hasil penjualan barang dan jasa yang dibebankan kepada pelanggan/pihak pemberi kerja”.

Menurut Kieso, Warfield dan Weygantd (2011:955) :

"Pendapatan adalah arus masuk bruto dari manfaat ekonomi yang timbul dari aktivitas normal entitas selama suatu periode, jika arus masuk tersebut 
mengakibatkan kenaikan ekuitas yang tidak berasal dari kontribusi penanaman modal".

Menurut Skousen, Stice dan Stice (2010:161) :

"pendapatan adalah arus masuk atau penyelesaian (atau kombinasi keduanya) dari pengiriman atau produksi barang, memberikan jasa atau melakukan aktivitas lain yang merupakan aktivitas."

Menurut Antonio (2011:204) :

"Pendapatan adalah kenaikan laba kotor dalam aset atau penurunan dalam liabilitas atau gabungan dari keduanya selama periode yang dipilih oleh pernyataan pendapatan yang berakibat dari investasi, perdagangan, memberikan jasa atau aktivitas lain yang bertujuan meraih keuntungan. Pendapatan diakui hanya jika kemungkinan besar manfaat ekonomi sehubungan dengan transaksi tersebut akan mengalir ke entitas. Akan tetapi, jika ketidakpastian timbul atas kolektibilitas jumlah yang telah termasuk dalam pendapatan, maka jumlah yang tidak tertagih atau jumlah pemulihan yang kemungkinannya tidak lagi besar diakui sebagai beban, bukan sebagai penyesuaian terhadap jumlah pendapatan yang diakui semula (PSAK No. 23 paragraf 22 )".

Berdasarkan definisi-definisi di atas, maka dapat disimpulkan bahwa pendapatan adalah jumlah masukan yang didapat atas jasa yang diberikan oleh perusahaan yang bisa meliputi penjualan produk dan atau jasa kepada pelanggan yang diperoleh dalam suatu aktivitas operasi suatu perusahaan untuk meningkatkan nilai aset serta menurunkan liabilitas yang timbul dalam penyerahan barang dan jasa.

\section{Sumber Pendapatan Bank Syariah}

Menurut PSAK No. 23, pendapatan adalah penghasilan yang timbul dari pelaksanaan aktivitas entitas yang normal dan dikenal dengan sebutan yang berbeda, seperti penjualan, penghasilan jasa, bunga, dividen, royalti, dan sewa. Berdasarkan UU No. 21 Tahun 2008 Pasal 19 Ayat 1, kegiatan usaha bank syariah yakni menghimpun dana, menyalurkan dana, dan melayani jasa lainnya.

Dari kegiatan usaha tersebut bank syariah mendapatkan penghasilan (income) berupa margin keuntungan, bagi hasil, dan fee (ujrah). Imbalan tersebut diperoleh bank syariah dari kegiatan usaha berupa pembiayaan (Wangsawidjaja, 2012:78).

\section{Pengertian Pembiayaan}

Pengertian pembiayaan menurut Kasmir (2014:85) :

"Penyediaan uang atau tagihan yang dapat dipersamakan dengan itu, berdasarkan persetujuan atau kesepakatan antara bank dengan pihak lain yang mewajibkan pihak yang dibiayai untuk mengembalikan uang atau tagihan tersebut setelah jangka waktu tertentu dengan imbalan atau bagi hasil".

Berdasarkan persetujuan atau kesepakatan antara Bank Syariah dan/atau UUS dan pihak lain yang mewajibkan pihak yang dibiayai dan/atau diberi fasilitas dana untuk mengembalikan dana tersebut setelah jangka waktu tertentu dengan imbalan ujrah, tanpa imbalan, atau bagi hasil. 


\section{Pengertian Akad Murabahah}

Menurut Sjahdeini (2014:193) :

"Murabahah adalah suatu jasa/produk pembiayaan yang diberikan oleh suatu lembaga pembiayaan berdasarkan prisnsip syariah (lembaga pembiayaan syariah) kepada nasabahnya yang membutuhkan dan memesan suatu barang tertentu."

\section{Pengertian Akad Musyarakah}

menurut sjahdeni (329:2014) :

\section{Profitabilitas}

Menurut Hery (2016:192) :

"profitabilitas merupakan rasio yang digunakan untuk mengukur kemampuan perusahaan dalam menghasilkan laba dari aktivitas normal bisnisnya. perusahaan adalah sebuah organisasi yang beroperasi yang bertujuan untuk menghasilkan keuntungan dengan cara menjual produk (barang/jasa) kepada para pelanggannya."

Rasio profitabilitas dikenal juga dengan rasio rentabilitas. Disamping untuk mengetahui kemampuan perusahaan dalam menghasilkan laba selama periode tertentu, rasio ini juga dapat mengukur tingkat efektivitas manajemen dalam menjalankan aktivitas perusahaan.

Menurut Pandia (2012:71), penilaian profitabilitas bank dapat dilihat dari komponen berikut:

a. Return On Assets (ROA)

b. Return On Equity (ROE)

c. Net Interest Margin (NIM)

d. Biaya Operasional Pendapatan Operasional (BOPO)
"Musyarakah dapat diartikan kedalam bahasa Indonesia dengan "kemitraan para pemodal" atau "perkongsian para pemodal"."

Pada metode pembiayaan musyarakah, bank dan nasabah bersepakat untuk bergabung dalam satu kemitraan (partnership) dalam jangka waktu tertentu. Kedua belah pihak menempatkan modal untuk membiayai suatu proyek dan bersepakat untuk membagi keuntungan bersih secara proporsional yang ditentukan diawal.

\section{Return On Assets (ROA)}

Menurut Hanafi (2012:42) :

"Return On Assets (ROA) adalah rasio yang digunakan untuk mengukur kemampuan perusahaan dalam menghasilkan laba bersih berdasarkan tingkat aset yang tertentu. Sedangkan menurut Sutrisno (2012:222) Return On Assets (ROA) adalah ukuran kemampuan perusahaan dan menghasilkan laba dengan semua aktiva yang dimilki oleh perusahaan."

Surat Edaran Otoritas Jasa Keuangan Nomor 10/SEOJK.03/2014 menyebutkan bahwa Return On Assets (ROA) dapat diukur melalui perbandingan antara laba sebelum pajak terhadap rata-rata total aset, seperti yang dituangkan dalam rumus berikut:

Return On Assets (ROA):

$$
=\frac{\text { Laba Sebelum Pajak }}{\text { Rata-rata Total Aset }} \times 100 \%
$$

Hanafi (2012:42) mengatakan, Rasio yang tinggi menunjukan efisiensi dan efektivitas pengelolaan aset, yang berarti semakin baik. Dengan kata lain, 
return on assets digunakan untuk mengukur efektivitas perusahaan dalam menghasilkan laba bersih dengan memanfaatkan aset yang dimilikinya. Semakin besar Return On Assets (ROA), berarti semakin besar pula tingkat keuntungan yang dicapai dari semakin baiknya posisi bank dari segi penggunaan aset .

\section{METODE PENELITIAN DAN ANALISIS}

\section{Metode yang digunakan}

Metode yang digunakan dalam melakukan penelitian ini adalah metode deskriptif dan metode verifikatif, karena adanya variabel-variabel yang akan ditelaah hubungannya, serta tujuannya untuk menyajikan gambaran secara terstruktur, faktual, dan akurat mengenai fakta serta hubungannya antara variabel yang diteliti, yaitu pengaruh pendapatan murabahah dan musyarakah terhadap profitabilitas (ROA).

\section{Uji Asumsi Klasik}

Uji asumsi klasik adalah uji yang harus dipenuhi sebelum melakukan analisis model regresi. Menurut Priyatno (2012:143), tujuan dari uji asumsi klasik adalah untuk menetapkan seberapa baik model yang digunakan dan cocok untuk menguji hipotesis yang telah dirumuskan, sehingga diperoleh model yang terbaik.

Sedangkan uji normalitas dengan cara analisis statistik dapat di uji dengan uji Kolmogorov-Smirnov. Kolmogorov-Smirnov digunakan untuk menguji normalitas data dengan sampel besar.
Uji Multikolinearitas

Menurut Ghozali (2013:105), Uji Multikolinearitas bertujuan untuk menguji apakah model regresi ditemukan adanya kolerasi antar variabel bebas (independen). Uji multikolinearitas perlu dilakukan jika jumlah variabel independen atau variabel bebas lebih dari satu. Ada berbagai metode yang dapat digunakan untuk mengetahui multikolinearitas, yaitu dengan melihat nilai Variance Inflation Factor (VIF) dan Tolerance.

1. Uji Autokolerasi

Uji Autokolerasi digunakan untuk mengetahui apakah dalam sebuah model regresi linier terdapat hubungan yang kuat positif maupun negatif antar data yang ada pada variabel-variabel penelitian (Umar, 2014:182).

2. Uji Heteroskedastisitas

Uji heteroskedastisitas dilakukan untuk mengetahui apakah dalam sebuah model regresi terjadi ketidaksamaan varian dari residual suatu pengamatan ke pengamatan lain, tetap disebut homokedastisitas. Sementara itu, untuk varians yang berbeda disebut heteroskedastisitas.

\section{Analisis Regresi Linear Berganda}

Analisis regresi linear berganda yaitu suatu teknik linear regresi yang variabel dependennya adalah merupakan fungsi linear dari beberapa variabel bebas. Regresi linear berganda sangat bermanfaat untuk meneliti pengaruh beberapa variabel yang berkolerasi dengan variabel yang di uji. Hubungan fungsi antara satu variabel 
dependen dengan lebih dari satu variabel independen dapat dilakukan dengan analisis regresi linear berganda, dimana Profitabilitas (ROA) sebagai variabel dependen sedangkan pendapatan Murabahah dan Pendapatan Musyarakah sebagai variabel independen.

\section{Analisis Koefisien Kolerasi}

Koefisien kolerasi merupakan analisis yang digunakan untuk mengetahui hubungan antara variabel bebas dengan variabel secara bersamasama dan untuk mengukur seberapa besar variabel bebas mampu menjelaskan variasi perubahan variabel terikat (Sugiyono, 2014:182).

\section{Analisis Koefisien Determinasi}

Analisis kolerasi dapat dilanjutkan dengan menghitung koefisien determinasi, dengan mengkuadratkan koefisien yang ditemukan (Sugiyono, 2014:185). Analisis ini digunakan untuk mengetahui besarnya pengaruh variabel independen terhadap variabel dependen yang dinyatakan dalam persentase.

\section{Uji Parsial (Uji t)}

Uji t digunakan untuk menguji hipotesa yang bersifat terpisah (parsial) yaitu antara $\mathrm{X}_{1}$ dengan $\mathrm{Y}$ dan $\mathrm{X}_{2}$ dengan $Y$. Untuk mengetahui apakah masing- masing variabel bebas secara signifikan terdapat hubungan dengan variabel tidak bebas.

\section{Uji Simultan (Uji f)}

Pada dasarnya uji statistik $\mathrm{f}$ menunjukkan apakah semua variabel independen (bebas) mempunyai pengaruh secara bersama-sama terhadap variabel dependen (terikat).

\section{HASIL PENELITIAN DAN PEMBAHASAN}

\section{Hasil Penelitian}

Penelitian ini dilakukan pada PT. Bank BNI Syariah menggunakan data triwulan selama 5 tahun yaitu periode tahun 2012 sampai dengan tahun 2016. Sebelum membahas pengaruh pendapatan murabahah dan musyarakah terhadap profitabilitas (ROA), terlebih dahulu dibahas perkembangan pendapatan murabahah, pendapatan musyarakah, dan profitabilitas (ROA) PT. Bank BNI Syariah selama periode 2012-2016.

\section{Perkembangan Pendapatan Murabahah Pada PT. Bank BNI Syariah Periode 2012-2016}

Berdasarkan hasil penelitian dan pembahasan, perkembangannya jumlah pendapatan murabahah sebagai berikut: 
Tabel Perkembangan Pendapatan Murabahah Per-Triwulan Pada PT. Bank BNI Syariah periode 2012-2016

\begin{tabular}{|c|c|c|c|c|}
\hline Tahun & Triwulan & $\begin{array}{l}\text { Pendapatan } \\
\text { Murabahah } \\
\text { (Rp. Jutaan) }\end{array}$ & $\begin{array}{l}\text { Perkembangan } \\
\text { (Rp. Jutaan) }\end{array}$ & Persentase \\
\hline \multirow{4}{*}{2012} & I & 111.050 & - & - \\
\hline & II & 236.166 & 125.116 & $112.67 \%$ \\
\hline & III & 370.559 & 134.393 & $56.91 \%$ \\
\hline & IV & 527.024 & 156.465 & $42.22 \%$ \\
\hline \multirow{4}{*}{2013} & I & 173.699 & -353.325 & $-67.04 \%$ \\
\hline & II & 369.196 & 195.497 & $112.55 \%$ \\
\hline & III & 595.205 & 226.009 & $61.22 \%$ \\
\hline & IV & 854.003 & 258.798 & $43.48 \%$ \\
\hline \multirow{4}{*}{2014} & I & 283.448 & -570.555 & $-66.81 \%$ \\
\hline & II & 599.670 & 316.222 & $111.56 \%$ \\
\hline & III & 948.773 & 349.103 & $58.22 \%$ \\
\hline & IV & 1.440 .710 & 491.937 & $51.85 \%$ \\
\hline \multirow{4}{*}{2015} & I & 417.637 & -1.023 .073 & $-71.01 \%$ \\
\hline & II & 849.185 & 431.548 & $103.33 \%$ \\
\hline & III & 1.297 .748 & 448.563 & $52.82 \%$ \\
\hline & IV & 1.741 .998 & 444.250 & $34.23 \%$ \\
\hline \multirow{4}{*}{2016} & $\mathrm{I}$ & 453.638 & -1.288 .360 & $-73.96 \%$ \\
\hline & II & 915.442 & 461.804 & $101.80 \%$ \\
\hline & III & 1.379 .731 & 464.289 & $50.72 \%$ \\
\hline & IV & 1.880 .955 & 501.224 & $36.33 \%$ \\
\hline
\end{tabular}

\section{Sumber : Laporan Keuangan Per-Triwulan pada PT. Bank BNI Syariah Periode} 2012-2016 (data diolah, 2018)

Dari tabel di atas dapat dilihat total pendapatan murabahah pada PT. Bank BNI Syariah periode tahun 20122016. Total pendapatan murabahah terjadi kenaikan dan penurunan atau terjadi fluktuatif cenderung meningkat atas data triwulan di tabel di atas tersebut. Perkembangan terbesar atau kenaikan terbesar pendapatan murabahah terjadi pada tahun 2012 triwulan II sebesar Rp. 125.116 Juta atau dengan pertumbuhan sebesar $112.67 \%$ dan kondisi pendapatan murabahah tertinggi terjadi pada tahun 2016 triwulan IV sebesar Rp1.880.955 Juta. Perkembangan terkecil atau penurunan terkecil pendapatan murabahah terjadi pada tahun 2016 triwulan I sebesar Rp. -1.288.360 Juta dan kondisi pendapatan murabahah terendah terjadi pada tahun 2012 triwulan I sebesar Rp. 111.050 Juta.

Untuk mengetahui lebih jelas perkembangan pembiayaan murabahah, dapat digambarkan dalam grafik seperti berikut: 


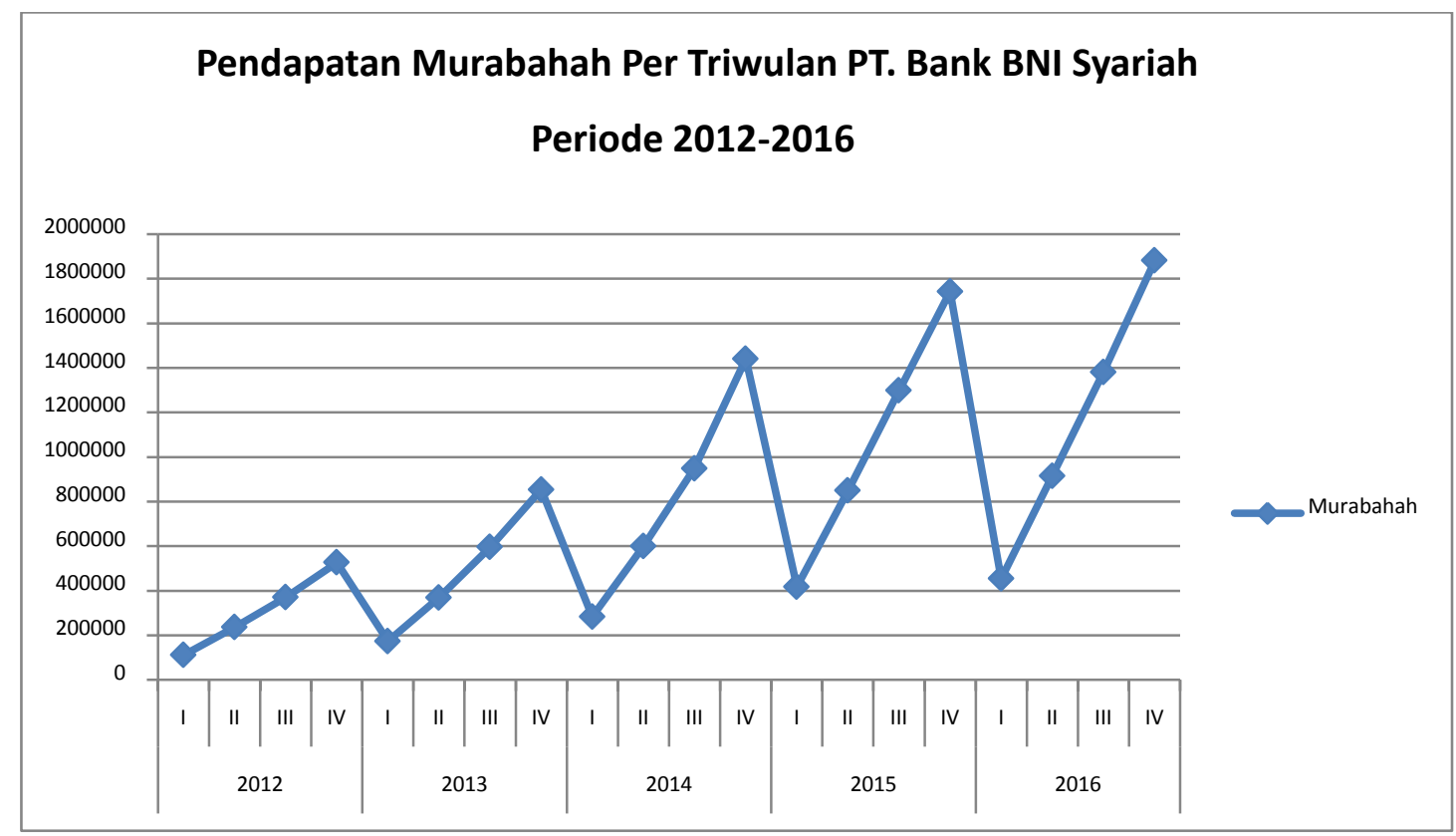

Berdasarkan grafik $\quad 4.1$ menunjukkan bahwa perkembangan pendapatan murabahah PT. Bank BNI Syariah Periode 2012-2016 per-triwulan berfluktuatif dan cenderung mengalami peningkatan pada tiap triwulannya. Kenaikan atau pertumbuhan pendapatan murabahah disebabkan oleh manajemen pembiayaan yang baik serta minat masyarakat yang semakin tinggi terhadap bank syariah.
Perkembangan Pendapatan Musyarakah pada PT. Bank BNI Syariah Periode 2012-2016

Menurut Cahyani dan Morita (36:2009) Pendapatan musyarakah merupakan keuntungan yang diperoleh bank berasal dari pembiayaan yang diberikan kepada nasabah dimana keuntungan tersebut dibagikan berdasarkan nisbah bagi hasil menurut kesepakatan di awal perjanjian.

Berdasarkan hasil penelitian dan pembahasan, perkembangan jumlah pendapatan musyarakah sebagaimana tabel di bawah ini.

Tabel Perkembangan Pendapatan Musyarakah Per-Triwulan Pada PT. Bank BNI Syariah periode 2012-2016

\begin{tabular}{|l|l|l|l|l|}
\hline Tahun & Triwulan & $\begin{array}{l}\text { Pendapatan } \\
\text { Musyarakah } \\
\text { (Rp.Jutaan) }\end{array}$ & $\begin{array}{l}\text { Perkembangan } \\
\text { (Rp.Jutaan) }\end{array}$ & Persentase \\
\hline 2012 & I & 24219 & & \\
\cline { 2 - 5 } & II & 49863 & 25644 & $105.88 \%$ \\
\cline { 2 - 5 } & III & 75835 & 25972 & $52.09 \%$ \\
\cline { 2 - 5 } & IV & 106069 & 30234 & $39.87 \%$ \\
\hline \multirow{3}{*}{2013} & I & 29707 & -76362 & $-71.99 \%$ \\
\cline { 2 - 5 } & II & 58954 & 29247 & $98.45 \%$ \\
\cline { 2 - 5 } & III & 87916 & 28962 & $49.13 \%$ \\
\hline
\end{tabular}




\begin{tabular}{|l|l|l|l|l|}
\hline & IV & 117623 & 29707 & $33.79 \%$ \\
\hline \multirow{3}{*}{2014} & I & 29766 & -87857 & $-74.69 \%$ \\
\cline { 2 - 5 } & II & 61806 & 32040 & $107.64 \%$ \\
\cline { 2 - 5 } & III & 95317 & 33511 & $54.22 \%$ \\
\cline { 2 - 5 } & IV & 132648 & 37331 & $39.17 \%$ \\
\hline \multirow{3}{*}{2015} & I & 37084 & -95564 & $-72.04 \%$ \\
\cline { 2 - 5 } & II & 74595 & 37511 & $101.15 \%$ \\
\cline { 2 - 5 } & III & 113642 & 39047 & $52.35 \%$ \\
\cline { 2 - 5 } & IV & 155862 & 42220 & $37.15 \%$ \\
\hline & I & 55280 & -100582 & $-64.53 \%$ \\
\cline { 2 - 5 } & II & 119780 & 64500 & $116.68 \%$ \\
\cline { 2 - 5 } & III & 184386 & 64606 & $53.94 \%$ \\
\cline { 2 - 5 } & IV & 254817 & 70431 & $38.20 \%$ \\
\hline
\end{tabular}

Sumber : Laporan Keuangan Per-Triwulan pada PT. Bank BNI Syariah Periode 2012-2016 (data diolah,2018)

Dari tabel 4.2 dapat dilihat perkembangan pendapatan musyarakah pada PT. Bank BNI Syariah Periode 2012-2016 per-triwulan. Perkembangan terbesar atau kenaikan terbesar pendapatan musyarakah terjadi pada tahun 2016 triwulan II sebesar Rp. 64.500 Juta atau sebesar $116.68 \%$ dan kondisi pendapatan musyarakah tertinggi terjadi pada tahun 2016 triwulan IV sebesar Rp. 254.817 Juta . Perkembangan terkecil atau penurunan terkecil pendapatan musyarakah terjadi pada tahun 2016 triwulan I sebesar Rp. 100.582 Juta dan kondisi pendapatan musyarakah terendah terjadi pada tahun 2012 triwulan I sebesar Rp. 24.219 Juta - Untuk mengetahui lebih jelas perkembangan pendapatan musyarakah, dapat digambarkan dalam grafik seperti berikut:

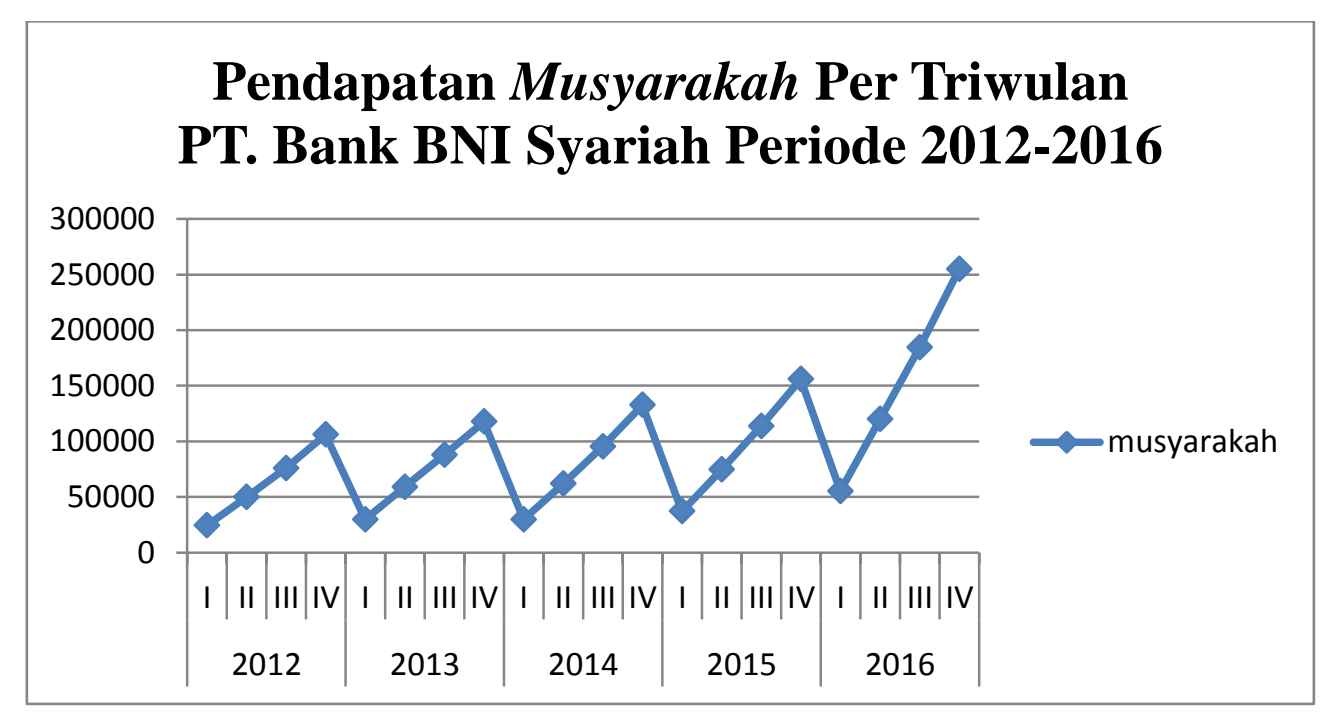


Berdasarkan grafik 4.2 menunjukkan bahwa perkembangan pendapatan musyarakah PT. Bank BNI Syariah Periode 2012-2016 per-triwulan berfluktuatif dan cenderung mengalami peningkatan pada tiap triwulannya. Kenaikan atau pertumbuhan pendapatan murabahah disebabkan oleh manajemen pembiayaan yang baik serta minat masyarakat yang semakin tinggi terhadap bank syariah.

\section{Perkembangan Profitabilitas Return} On Asset (ROA) pada PT. Bank BNI Syariah Periode 2012-2016

Menurut Hanafi (2012:42), yang digunakan untuk mengukur kemampuan perusahaan dalam menghasilkan laba bersih berdasarkan tingkat aset yang tertentu. Sedangkan menurut Sutrisno (2012:222) Return On Assets (ROA) adalah ukuran kemampuan perusahaan dan menghasilkan laba dengan semua aktiva yang dimilki oleh perusahaan.

Berikut adalah data jumlah profitabilitas Return On Asset (ROA) dan perkembangannya, dapat dilihat pada tabel di bawah ini.

\begin{tabular}{|l|l|l|l|}
\hline Tahun & Triwulan & ROA (\%) & Perkembangan \\
\hline 2012 & I & 0.63 & - \\
\cline { 2 - 4 } & II & 0.65 & 0.02 \\
\cline { 2 - 4 } & III & 1.31 & 0.66 \\
\cline { 2 - 4 } & IV & 1.48 & 0.17 \\
\hline 2013 & I & 1.62 & 0.14 \\
\cline { 2 - 4 } & II & 1.24 & -0.38 \\
\cline { 2 - 4 } & III & 1.22 & -0.02 \\
\cline { 2 - 4 } & IV & 1.37 & 0.15 \\
\hline 2014 & I & 1.22 & -0.15 \\
\cline { 2 - 4 } & II & 1.11 & -0.11 \\
\cline { 2 - 4 } & III & 1.11 & 0 \\
\cline { 2 - 4 } & IV & 1.27 & 0.16 \\
\hline 2015 & I & 1.20 & -0.07 \\
\cline { 2 - 4 } & II & 1.30 & 0.1 \\
\cline { 2 - 4 } & III & 1.32 & 0.02 \\
\cline { 2 - 4 } & IV & 1.43 & 0.11 \\
\hline 2016 & I & 1.65 & 0.22 \\
\cline { 2 - 4 } & II & 1.59 & -0.06 \\
\cline { 2 - 4 } & III & 1.53 & -0.06 \\
\cline { 2 - 4 } & IV & 1.44 & -0.09 \\
\hline
\end{tabular}

Sumber : Laporan Keuangan Per-Triwulan pada PT. Bank BNI Syariah Periode 2012-2016 (data diolah,2018) 
Dari tabel 4.3 dapat dilihat perkembangan Return On Asset (ROA) pada PT. Bank BNI Syariah Periode 2012-2016 per-triwulan. Perkembangan terbesar atau kenaikan terbesar ROA terjadi pada triwulan III tahun 2012 sebesar $0,66 \%$ dan kondisi ROA tertinggi terjadi pada triwulan I tahun 2016 sebesar 1,65\%. Perkembangan terkecil atau penurunan terbesar ROA terjadi pada triwulan II pada tahun 2013 sebesar $-0,38 \%$ dan kondisi ROA terendah terjadi pada triwulan I tahun 2012 sebesar 0,63\%. Untuk mengetahui lebih jelas perkembangan pembiayaan ROA, dapat digambarkan dalam grafik seperti berikut:

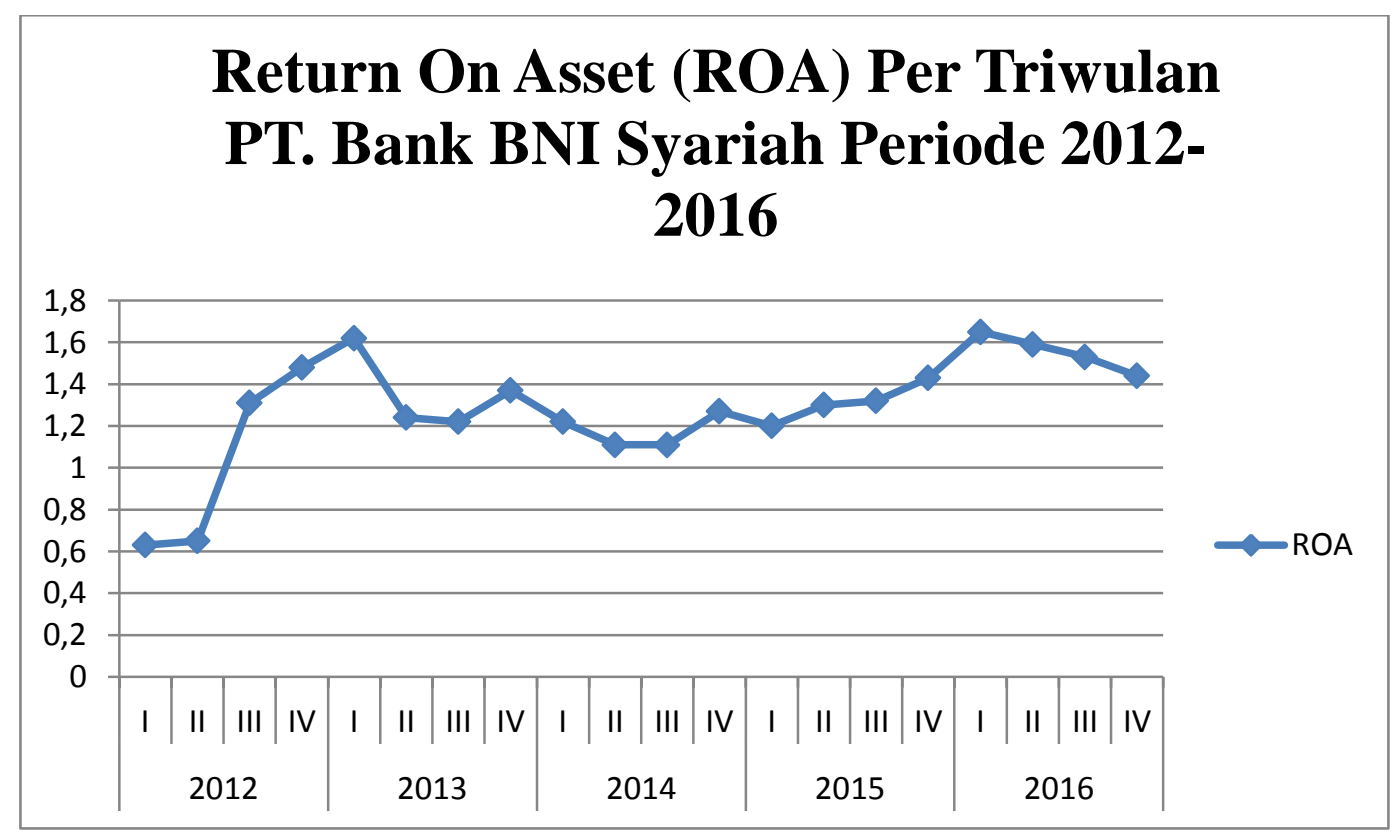

Dari tabel dan grafik diatas diperoleh gambaran perkembangan Return On Asset (ROA) yang berfluktuatif, perkembangan ROA cenderung menurun pada tahun 2013 triwulan I sampai 2014 triwulan III. Ini memperlihatkan adanya inkonsistensi Bank BNI Syariah dalam mendapatkan profitabilitas dari tahun 2012-2016.

Sementara nilai ROA yang berada dibawah standar Bank Indonesia (BI) bersumber dari Surat Edaran Bank Indonesia No 6/23/DPNP tanggal 31 Mei 2004 sebesar 1,25\%. Return On Asset (ROA) yang dimiliki oleh PT. Bank BNI Syariah pada triwulan I tahun
2012 triwulan 1 hingga triwulan II pada tahun 2012 berada antara 0,63 sampai dengan $0,65 \%$, serta pada tahun 2013 triwulan II sampai dengan 2015 triwulan 1 berada pada $1,24 \%$ sampai dengan 1,20\%. artinya bahwa hal ini harus mendapatkan perhatian lebih bagi pihak bank karena bank yang sehat adalah bank yang mampu mendapatkan ROA melebihi batas standar yang diberikan oleh Bank Indonesia, ini bertujuan agar kinerja Bank BNI Syariah dapat berjalan baik untuk kedepannya. 


\section{Uji Hipotesis}

Untuk dapat mengetahui pengaruh pendaptan murabahah dan pendapatan musyarakah terhadap profitabilitas (ROA), maka dilakukan analisis data dengan menggunakan uji asumsi klasik, analisis regresi linear berganda, analisis koefisien korelasi, analisis koefisien determinasi, uji $t$ (parsial) dan uji f (simultan). Untuk mempermudah pengolahan data, penulis menggunakan software statistic (SPSS, 25).

\section{Uji Asumsi Klasik}

Sebelum melakukan uji regresi linear berganda dalam penelitian terlebih dahulu penulis melakukan uji asumsi klasik. Pengujian asumsi klasik dalam penelitian ini terdiri dari empat pengujian yaitu, uji normalitas, uji multikolinearitas, uji autokolerasi, uji heteroskedastisitas. Harus terpenuhinya asumsi klasik karena agar diperoleh model regresi dengan estimasi yang tidak bias dan pengujian dapat dipercaya.

\section{Uji Normalitas}

Untuk menguji normalitas data, penelitian ini menggunakan dua buah pengujian yaitu uji normalitas uji One Sample Kolmogorov-Smirnov dengan normal P-Plot. Berikut ini merupakan uji normalitas dengan menggunakan uji One Sample Kolmogorov-Smirnov, yaitu jika nilai probabilitas untuk residual lebih besar dari 0,05 maka data terdistribusi dengan normal. Dibawah ini merupakan hasil pengujian One Sample Kolmogorov-Smirnov, dapat dilihat pada tabel 4.4 sebagai berikut:

Berikut ini merupakan tabel dari uji One Sample Kolmogorov-Smirnov dari, dapat dilihat pada Tabel 4.4 sebagai berikut:

\section{Tabel 4.4 One-Sample Kolmogorov-Smirnov Test One-Sample Kolmogorov-Smirnov Test}

\begin{tabular}{|c|c|c|}
\hline & & $\begin{array}{l}\text { Unstandardized } \\
\text { Residual }\end{array}$ \\
\hline \multicolumn{2}{|l|}{$\mathrm{N}$} & 20 \\
\hline \multirow[t]{2}{*}{ Normal Parameters ${ }^{\mathrm{a}, \mathrm{b}}$} & Mean & .0000000 \\
\hline & Std. Deviation & .21835591 \\
\hline \multirow[t]{3}{*}{ Most Extreme Differences } & Absolute & .127 \\
\hline & Positive & .103 \\
\hline & Negative & -.127 \\
\hline \multicolumn{2}{|l|}{ Test Statistic } & .127 \\
\hline \multicolumn{2}{|l|}{ Asymp. Sig. (2-tailed) } & $.200^{\mathrm{c}, \mathrm{d}}$ \\
\hline
\end{tabular}
a. Test distribution is Normal.
b. Calculated from data.
c. Lilliefors Significance Correction.
$\mathrm{d}$. This is a lower bound of the true significance.

Sumber: SPSS 25 (Data diolah, 2018) 
Berdasarkan tabel 4.4 diatas, uji normalitas dengan menggunakan uji One Sample Kolmogorov-Smirnov berdistribusi normal, dimana berdasarkan hasil nilai signifikan Kolmogorov-Smirnov menunjukkan sebesar 0,200 dimana hasil ini menunjukkan hasil diatas signifikansi yaitu $0,200>0,05$, artinya data residual berdistribusi normal dan memenuhi asumsi normalitas.
Berikut merupakan uji normalitas dengan menggunakan uji $P$ Plot. Dalam hal ini untuk mengetahui apakah distribusi normal atau tidak, dapat diketahui dengan menggunakan penyebaran data melalui grafik. Jika datanya menyebar di sekitar garis diagonal dan mengikuti arah garis diagonalnya, model regresi memenuhi asumsi normalitas (Umar, 2014:181). Uji P-Plots dapat dilihat pada gambar 4.4 berikut :

\section{Gambar 4.4 Normal P-Plot Regression Standarized Residual}

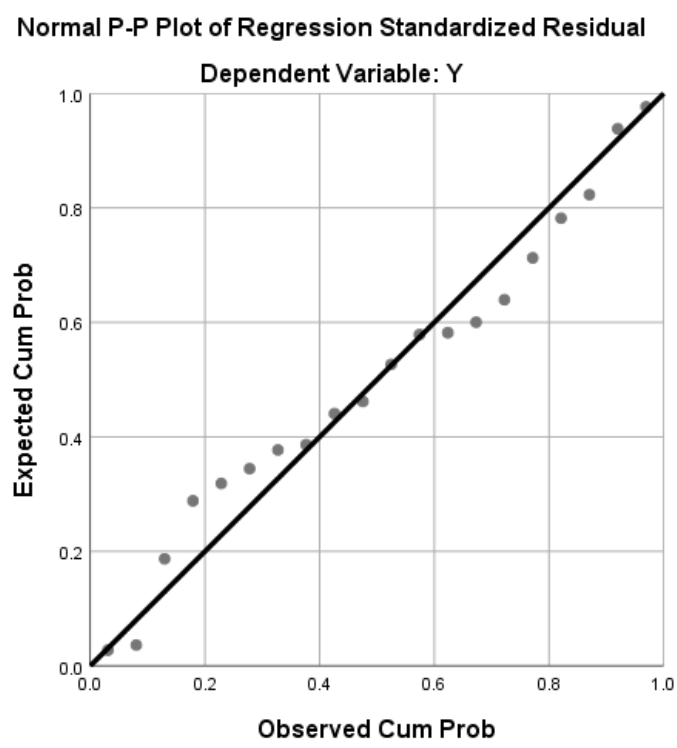

Sumber: SPSS 25 (Data diolah, 2018)

Berdasarkan grafik Normal $P$ Plot, dapat dilihat bahwa data (titiktitik) menyebar di sekitar garis diagonal dan mengikuti arah garis diagonal yang menunjukkan bahwa pola berdistribusi normal, maka model regresi memenuhi asumsi normalitas.
Kesimpulan dari kedua uji normalitas tersebut menunjukkan bahwa data tersebut berdistribusi normal.

\section{Uji Multikolinearitas}

Uji Multikolinearitas digunakan untuk mengetahui apakah pada model regresi ditemukan adanya kolerasi antar variabel bebas (independen). Ada berbagai metode yang dapat digunakan 
untuk mengetahui multikolinearitas, yaitu dengan melihat nilai Variance Inflation Factor (VIF) dan Tolerance.

Dibawah ini merupakan hasil pengujian multikolinearitas, dapat dilihat pada tabel 4.5 sebagai berikut:

\section{Tabel 4.5 Hasil Pengujian}

Multikolinearitas

\begin{tabular}{|l|r|r|}
\hline \multirow{2}{*}{ Model } & \multicolumn{2}{|c}{ Collinearity Statistics } \\
\hline Constant & \multicolumn{2}{|c}{ Tolerance } \\
\hline Murabahah & 0.115 & \\
\hline Musyarakah & 0.115 & 6.45 \\
\hline
\end{tabular}

Sumber: SPSS 25 (Data diolah, 2018)

Dari tabel 4.5, dapat dilihat bahwa hasil uji multikolinearitas mempunyai nilai Tolerance dari variabel Murabahah dan Musyarakah sebesar 0,115>0,10. Nilai VIF dari variabel Murabahah dan Musyarakah sebesar $6,456<10$. Maka dapat disimpulkan bahwa antar variabel independen tidak terjadi persoalan multikolinearitas.

\section{Uji Autokolerasi}

Dalam penelitian ini penulis menggunakan uji Runs Test untuk mengetahui terjadi atau tidaknya autokolerasi. Untuk mengukur sampai sejauh mana terdapat kondisi serial (autokolerasi) dalam residu, yaitu dengan melihat nilai Assymp. Sig pada nilai Unresidual dalam tabel Run Test. Jika nilai Assymp. Sig > 0,05 maka hal ini menunjukkan tidak adanya autokolerasi. Sedangkan jika nilai
Assymp. Sig $<0,05$ maka hal ini menunjukkan adanya autokolerasi.

Pada tabel 6 dibawah ini menunjukkan hasil uji autokolerasi, sebagai berikut:

\section{Tabel Hasil Uji Autokolerasi Runs} Test

Runs Test

\begin{tabular}{lr} 
& \multicolumn{2}{c}{ Unstandardized } \\
& Residual \\
\hline Test Value $^{\mathrm{a}}$ & -.00336 \\
\hline Cases < Test Value & 10 \\
\hline Cases >= Test Value & 10 \\
\hline Total Cases & 20 \\
\hline Number of Runs & 9 \\
\hline Z & -.689 \\
\hline Asymp. Sig. (2-tailed) & .491 \\
\hline
\end{tabular}

a. Median

\section{Sumber: SPSS 25 (Data diolah, 2018)}

Berdasarkan tabel 6 hasil uji autokolerasi dengan menggunakan Runs Test maka diperoleh nilai Assymp. Sig sebesar 0,491 dimana hasil ini sudah melebihi ketentuan nilai Assymp. Sig yaitu $0,491>0,05$. Maka dapat disimpulkan bahwa data tidak terjadi autokolerasi.

\section{Uji Heteroskedastisitas}

Dalam penelitian ini, penulis menggunakan grafik scatterplot untuk mengetahui ada atau tidaknya heteroskedastisitas.

Dibawah ini merupakan hasil pengujian heteroskedastisitas, dapat dilihat pada gambar 4.5 berikut: 


\section{Gambar 4.5 Uji Scatterplot}

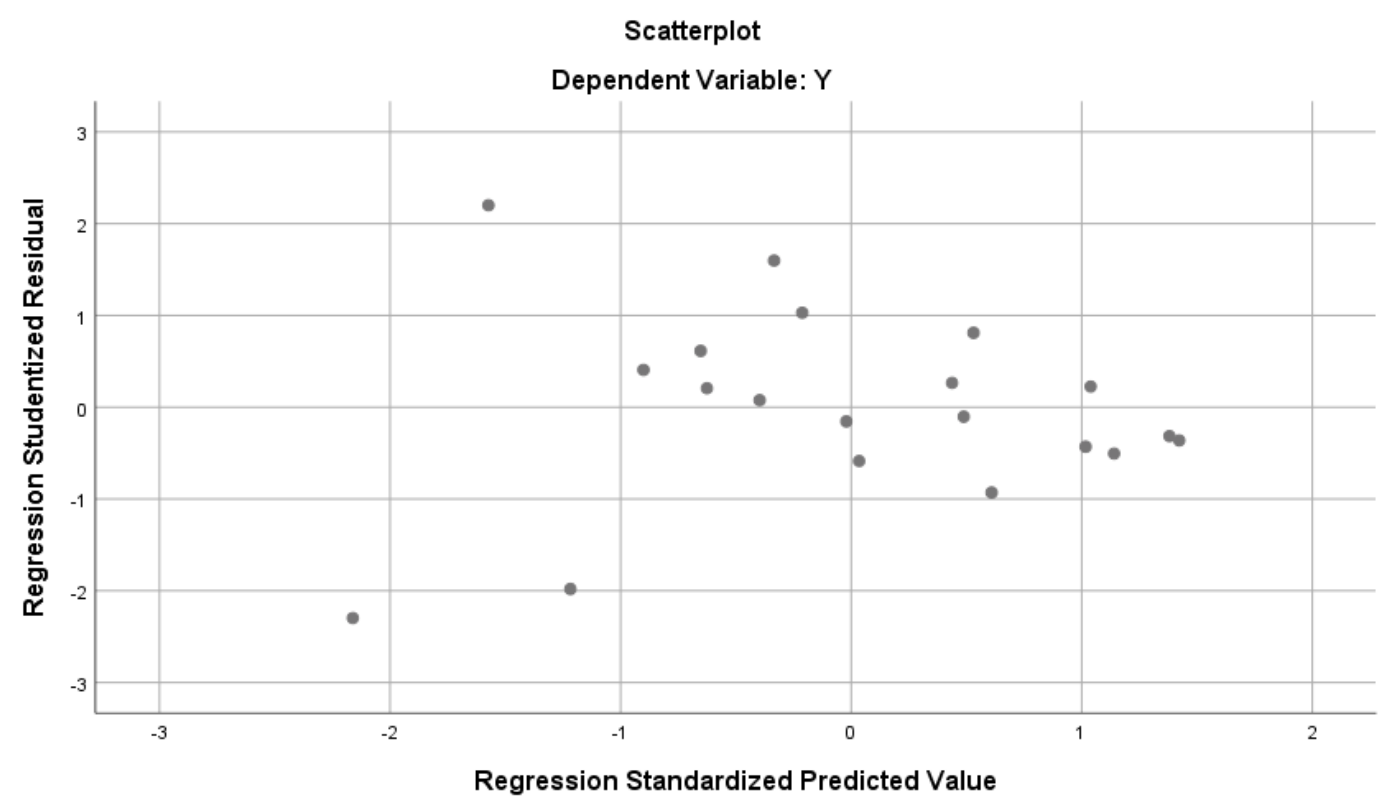

Sumber: SPSS 25 (Data diolah, 2018)

Berdasarkan gambar 5, dapat dilihat penyebaran titik titik tidak berpola, titik-titik menyebar secara acak. Titik-titik menyebar diatas dan dibawah angka 0 pada sumbu Y. Maka dapat disimpulkan bahwa tidak terjadi heteroskedastisitas dalam model regresi ini.

\section{Analisis Regresi Linear Berganda}

Adapun persamaan umum regresi linear berganda yaitu sebagai berikut:

$$
\mathrm{Y}=\mathrm{a}+\mathrm{b} 1 \mathrm{X}_{1}+\mathrm{b} 2 \mathrm{X}_{2}
$$

\section{Tabel 7 Hasil Regresi Linear Berganda}

\section{Coefficients $^{\mathrm{a}}$}

\begin{tabular}{llr|r|r} 
& \multicolumn{2}{c|}{ B } & \multicolumn{1}{c|}{ Std. Error } & Beta \\
\hline 1 & (Constant) & -6.622 & .940 & \\
\hline X1 & .183 & .172 & \\
\hline X2 & -.017 & .210 \\
\hline
\end{tabular}

a. Dependent Variable: Y

Sumber : SPSS 25 (Data diolah, 2018)

Berdasarkan Tabel 4.7 diatas maka dapat disusun persamaan regresi linear berganda yaitu sebagai berikut:

$$
Y=-6,622+0,183 X_{1}+-0,017 X_{2}
$$

Dari persamaan diatas maka dapat dijelaskan sebagai berikut:

1. Nilai konstanta (a) sebesar 6.622. Menyatakan bahwa ketika variabel bebas Pendapatan Murabahah (X $\left.{ }_{1}\right)$ dan Musyarakah $\left(\mathrm{X}_{2}\right)$ nilainya adalah 0, maka Profitabilitas StandarRi@A nilainya sebesar $-6,622 \%$.

\begin{tabular}{l|l|l} 
Coefficients & t & Sig.
\end{tabular} 
2. Nilai koefisien regresi variabel Pembiayaan Murabahah $\left(\mathrm{X}_{1}\right)$ bernilai $\quad-0.183$, positif. Hal ini menunjukkan hubungan yang searah antara Pendapatan Murabahah $\left(\mathrm{X}_{1}\right)$ dengan Profitabilitas ROA (Y), menyebabkan dimana setiap peningkatan $1 \%$ Pendapatan Murabahah maka akan Meningkatkan Profitabilitas ROA (Y) sebesar 0,183\%.

3. Nilai koefisien regresi variabel Pendapatan Musyarakah $\left(\mathrm{X}_{2}\right)$ bernilai $-0,017$, nilainya negatif. Hal ini menunjukkan adanya hubungan yang tidak searah antara Pendapatan Musyarakah
$\left(\mathrm{X}_{2}\right)$ dengan Profitabilitas ROA (Y), menyebabkan dimana setiap peningkatan $1 \%$ Pendapatan Musyarakah maka akan mengurangi Profitabilitas ROA (Y) sebesar $-0,017 \%$.

\section{Analisis Koefisien Korelasi (R)}

Koefisien kolerasi merupakan analisis yang digunakan untuk mengetahui hubungan antara variabel bebas dengan variabel secara bersamasama dan untuk mengukur seberapa besar variabel bebas mampu menjelaskan variasi perubahan variabel terikat (Sugiyono, 2014:182).

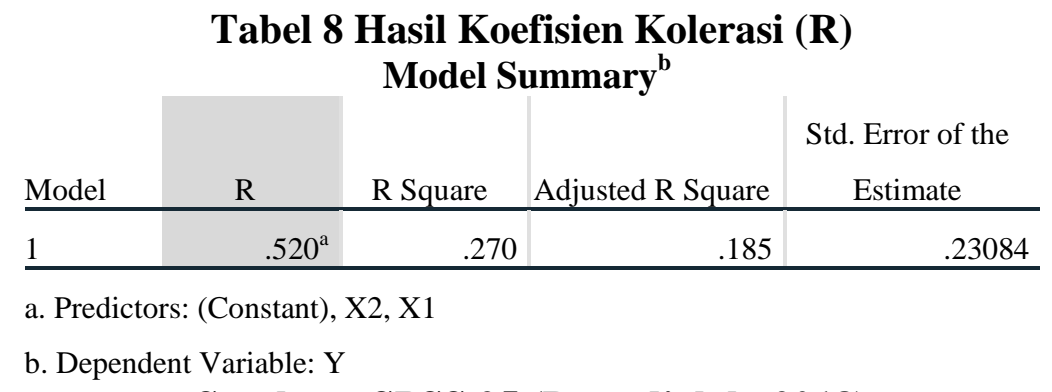

Sumber : SPSS 25 (Data diolah, 2018)

Berdasarkan tabel 4.8 diatas menunjukkan bahwa nilai koefisien kolerasi sebesar 0,520. Nilai tersebut berada pada interval koefisien 0,400 0,599 yang menunjukkan hubungan sedang, sesuai dengan pedoman interprestasi terhadap koefisien kolerasi menurut Sugiyono :
Tabel 9 Interprestasi Koefisien

\section{Kolerasi}

\begin{tabular}{|c|c|}
\hline $\begin{array}{c}\text { Interval } \\
\text { Koefisien }\end{array}$ & $\begin{array}{c}\text { Tingkat } \\
\text { Hubungan }\end{array}$ \\
\hline $0,000-0,199$ & Sangat Rendah \\
\hline $0,200-0,399$ & Rendah \\
\hline $\mathbf{0 , 4 0 0 - \mathbf { 0 , 5 9 9 }}$ & Sedang \\
\hline $0,600-0,799$ & Kuat \\
\hline $0,800-1,000$ & Sangat Kuat \\
\hline
\end{tabular}

Sumber: Sugiyono (2014:184) 
Analisis Koefisien Determinasi $\left(\mathbf{r}^{2}\right)$

Analisis ini digunakan untuk mengetahui besarnya pengaruh variabel independen terhadap variabel dependen yang dinyatakan dalam persentase. Penelitian pada pengaruh Pendapatan Murabahah $\left(\mathrm{X}_{1}\right)$ dan Musyarakah $\left(\mathrm{X}_{2}\right)$ terhadap Profitabilitas ROA (Y) diperoleh koefisien determinasi sebagai berikut :

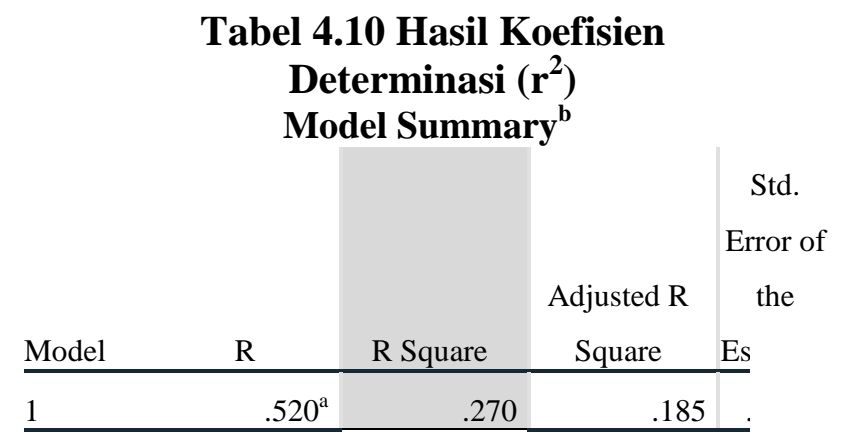

a. Predictors: (Constant), X2, X1

b. Dependent Variable: Y

Sumber : SPSS 25 (Data diolah, 20181

Berdasarkan tabel 4.10 diata diperoleh nilai $\mathrm{R}$-Square sebesar 0,27 atau $27 \%$ Hal ini menunjukkan bahw kedua variabel bebas, yaitu Pendapata Murabahah dan Musyaraka ${ }_{i \text { a }}$ memberikan kontribusi sebesar 27\% terhadap Profitabilitas ROA pada PT. Bank BNI Syariah periode 2012-2016, sementara sisanya yaitu sebesar $73 \%$ dipengaruhi oleh faktor-faktor lain yang tidak diteliti. Hal ini diperoleh dari perhitungan rumus koefisien determinasi yaitu:

$$
\begin{gathered}
K_{d}=r^{2} \times 100 \% \\
K_{d}=0,270 \times 100 \%=27 \%
\end{gathered}
$$

Uji Parsial (Uji t)
Uji t digunakan untuk menguji hipotesa yang bersifat terpisah (parsial) yaitu antara $\mathrm{X}_{1}$ dengan $\mathrm{Y}$ dan $\mathrm{X}_{2}$ dengan Y.

Tingkat keyakinan yang digunakan dalam penelitian ini adalah sebesar $95 \%$ dengan tarif nyata $5 \%(\alpha=$ $0,05)$. Tingkat signifikansi 0,05 atau $5 \%$ artinya kemungkinan besar dari hasil penarikan kesimpulan memiliki probabilitas $95 \%$ atau toleransi sebesar $5 \%$.

Pada uji $t$ atau uji parsial ini, nilai probabilitas dapat dilihat pada hasil pengujian yang sudah diolah pada tabel 4.11, sebagai berikut:

Tabel 4.11 Hasil Uji Parsial (Uji t) Coefficients $^{\mathrm{a}}$

Unstandardized Standardized

Coefficients Coefficients B Std. Error Beta

\begin{tabular}{|c|c|c|c|c|c|}
\hline (Constant) & $\begin{array}{r}- \\
6.62 \\
2\end{array}$ & .940 & & -7.046 & .000 \\
\hline $\mathrm{X} 1$ & .183 & .172 & .559 & 1.062 & .303 \\
\hline $\mathrm{X} 2$ & -.017 & .210 & -.043 & -.081 & .936 \\
\hline
\end{tabular}
Sig.

Dependent Variable: Y

Sumber : SPSS 25 (Data diolah, 2018)

Berdasarkan tabel 4.11 diatas dapat diketahui bahwa untuk pendapatan murabahah nilai $t_{\text {hitung }}<$ $\mathrm{t}_{\text {tabel }}$ sebesar 1,062 < 1,739 (df (n-k) 20$3=17, \alpha=0,05)$. Dan tingkat signifikansi 0,303 yang berarti nilai tersebut lebih besar dari 0,05. Dari hasil pengujian diatas maka dapat disimpulkan bahwa Ho diterima dan $\mathrm{Ha}$ ditolak, artinya bahwa Pendapatan Murabahah $\left(\mathrm{X}_{1}\right)$ secara parsial mempunyai hubungan positif 
berpengaruh namun tidak signifikan terhadap Profitabilitas (ROA).

Sedangkan untuk Pendapatan Musyarakah diketahui bahwa nilai $t_{\text {hitung }}$ $<\mathrm{t}_{\text {tabel }}$ sebesar $-0,081<1,739$ dan tingkat signifikansi 0,936 yang berarti nilai tersebut lebih besar dari 0,05. Dari hasil pengujian diatas maka dapat disimpulkan bahwa Ho diterima dan $\mathrm{Ha}$ ditolak, artinya bahwa Pendapatan Musyarakah $\left(\mathrm{X}_{2}\right)$ secara parsial berpengaruh namun tidak signifikan terhadap Profitabilitas (ROA).

\section{Uji Simultan (Uji f)}

Pada dasarnya uji statistik $f$ menunjukkan apakah semua variabel independen (bebas) mempunyai pengaruh secara bersama-sama terhadap variabel dependen (terikat).

Tingkat keyakinan yang digunakan dalam penelitian ini adalah sebesar $95 \%$ dengan taraf nyata 5\% $(\alpha=$ $0,05 \%)$. Tingkat signifikansi 0,05 atau 5 $\%$ artinya kemungkinan besar dari hasil penarikan kesimpulan memiliki probabilitas $95 \%$ atau toleransi sebesar $5 \%$.

Pada uji $f$ atau uji simultan ini, nilai probabilitas dapat dilihat pada hasil pengujian yang sudah diolah pada tabel 4.12, sebagai berikut:

Tabel 4.12 Hasil Uji Simultan (Uji f)

\begin{tabular}{|c|c|c|c|}
\hline \multirow[b]{2}{*}{ Model } & & & $\mathrm{ANOVA}^{\mathrm{a}}$ \\
\hline & & Sum of Squares & $\mathrm{df}$ \\
\hline 1 & Regression & .336 & 2 \\
\hline & Residual & .906 & 17 \\
\hline & Total & 1.242 & 19 \\
\hline
\end{tabular}

a. Dependent Variable: Y

b. Predictors: (Constant), X2, X1

Sumber : SPSS 25 (Data diolah, 2018)

Berdasarkan tabel 4.12 diatas dapat diketahui bahwa nilai $F_{\text {hitung }}$ sebesar 3,150 dengan tingkat signifikan 0,069. Dimana tingkat signifikansi lebih besar dari 0,05 , sedangkan nilai $F_{\text {hitung }}$ sebesar 3,150< $\mathrm{F}_{\text {tabel }} 3,59$ sehingga nilai sebesar 3,150 < dari 3,59 maka dapat disimpulkan bahwa Ho diterima dan $\mathrm{Ha}$ ditolak, artinya bahwa terdapat hubungan namun tidak signifikan antara variabel pendapatan Murabahah $\left(\mathrm{X}_{1}\right)$ dan Musyarakah $\left(\mathrm{X}_{2}\right)$ secara simultan terhadap Profitabilitas (ROA) (Y).

\section{Pembahasan Penelitian}

Berdasarkan hasil penelitian berkaitan dengan pengaruh Pendapatan Murabahah $\left(\mathrm{X}_{1}\right)$ dan Musyarakah $\left(\mathrm{X}_{2}\right)$ terhadap Profitabilitas ROA (Y) diperoleh pembahasan sebagai berikut:

\section{Pengaruh Pendapatan Murabahah $\left(X_{1}\right)$ terhadap Profitabiilitas ROA (Y) Secara Parsial}

Hasil pengujian secara parsial (Uji t) diperoleh nilai Pendapatan Murabahah sebesar 1,062 dengan signifikansi sebesar 0,303. Nilai signifikansi variabel Pendapatan Murabahah menunjukkan nilai tersebut diatas tingkat signifikansi yang ditetapkan sebesar 5\% $(\alpha=0,05)$ dimana 0,303>0,05 maka Ho diterima, yang artinya bahwa secara parsial Pendapatan Murabahah $\quad\left(\mathrm{X}_{1}\right)$ Mean Square. F fuburgan Sig. positif berpengaruh namun ${ }^{3.150}$ tidak ${ }^{.069}$ signifikan terhadap Profitabilitas ROA (Y) pada 19 PT. Bank BNI Syariah i periode-20122016.

Pengaruh Pendapatan Musyarakah $\left(\mathrm{X}_{2}\right)$ terhadap Profitabilitas ROA (Y) secara parsial 
Hasil pengujian parsial (Uji t) diperoleh nilai Pendapatan Musyarakah bahwa nilai $t_{\text {hitung }}>\mathrm{t}_{\text {tabel }}$ sebesar $-0,081$ $<1,720$ dan tingkat signifikansi 0,936 yang berarti nilai tersebut lebih besar dari 0,05. Dari hasil pengujian diatas maka dapat disimpulkan bahwa Ho diterima dan Ha ditolak, artinya bahwa Pendapatan Musyarakah $\left(\mathrm{X}_{2}\right)$ secara parsial berpengaruh negatif namun tidak signifikan terhadap Profitabilitas (ROA) pada PT. Bank BNI Syariah periode 2012-2016.

\section{Pengaruh Pendapatan Murabahah $\left(\mathrm{X}_{1}\right)$ dan Pendapatan Musyarakah $\left(\mathrm{X}_{2}\right)$ terhadap Profitabilitas ROA (Y) secara simultan}

Hasil pengujian simultan (Uji f) diperoleh nilai $F_{\text {hitung sebesar 3,150 }}$ dengan tingkat signifikansi 0,69 . Dengan mengambil taraf signifikansi $\alpha$ $=0,05$ maka $F_{\text {tabel }}$ sebesar 3,59 sehingga nilai $F_{\text {hitung }} 3,150<F_{\text {tabel }} 3,49$ dengan tingkat signifikansi lebih besar dari taraf signifikansi $0,69<0,05$ maka dapat disimpulkan bahwa Ho diterima dan Ha ditolak, artinya Pendapatan Murabahah dan Musyarakah secara simultan berpengaruh namun tidak signifikan terhadap Profitabilitas ROA pada PT. Bank BNI Syariah.

Nilai Koefisien Determinasi $\left(r^{2}\right)$ untuk pendapatan murabahah dan musyarakah terhadap profitabilitas ROA juga dinilai kurang baik yaitu memperoleh $27 \%$. Hal ini dapat membawa hasil yang kurang menguntungkan bagi pihak bank, jika penyaluran pembiayaan tersebut dalam pengembaliannya berjalan tidak lancar.
Dengan demikian profitabilitas menjadi faktor penting dalam penilaian aktivitas perbankan syariah dalam kegiatannya.

\section{KESIMPULAN DAN SARAN Kesimpulan}

Berdasarkan pada hasil penelitian dan pembahasan maka dapat disimpulkan sebagai berikut:

1. Perkembangan pendapatan murabahah pada PT Bank BNI Syariah periode 2012-2016. Perkembangan pendapatan murabahah cenderung meningkat setiap tahunnya. Perkembangan terbesar atau kenaikan terbesar pendapatan murabahah terjadi pada tahun 2012 triwulan II sebesar Rp. 125.116 Juta atau dengan pertumbuhan sebesar $112.67 \%$ dan kondisi pendapatan murabahah tertinggi terjadi pada tahun 2016 triwulan IV sebesar Rp1.880.955 Juta. Perkembangan terkecil atau penurunan terkecil pendapatan murabahah terjadi pada tahun 2016 triwulan I sebesar Rp. 1.288.360 Juta.

2. perkembangan pendapatan musyarakah pada PT. Bank BNI Syariah Periode 2012-2016. Perkembangan pendapatan musyarakah mengalami peningkatan setiap tahunnya. Perkembangan terbesar atau kenaikan terbesar pendapatan musyarakah terjadi pada tahun 2016 triwulan II sebesar Rp. 64.500 Juta atau sebesar $116.68 \%$ dan kondisi pendapatan musyarakah tertinggi terjadi pada tahun 2016 triwulan IV sebesar Rp. 254.817 Juta . Perkembangan terkecil 
atau penurunan terkecil pendapatan musyarakah terjadi pada tahun 2016 triwulan I sebesar Rp. -100.582 Juta.

3. perkembangan Return On Asset (ROA) pada PT. Bank BNI Syariah Periode 2012-2016 pertriwulan. Perkembangan terbesar atau kenaikan terbesar ROA terjadi pada triwulan III tahun 2012 sebesar $0,66 \%$ dan kondisi ROA tertinggi terjadi pada triwulan I tahun 2016 sebesar $1,65 \%$. Perkembangan terkecil atau penurunan terbesar ROA terjadi pada triwulan II pada tahun 2013 sebesar $-0,38 \%$.

4. Pengaruh pendapatan murabahah dan pendapatan musyarakah terhadap Profitabilitas ROA pada PT. Bank BNI Syariah periode 2011-2016.

a) Hasil pengujian secara parsial diperoleh nilai Pendapatan Murabahah sebesar 1,062 dengan signifikansi sebesar 0,303. Nilai signifikansi variabel Pendapatan Murabahah menunjukkan nilai tersebut diatas tingkat signifikansi yang ditetapkan sebesar 5\% $(\alpha=0,05)$ dimana 0,303 >0,05 maka Ho diterima, yang artinya bahwa secara parsial Pendapatan Murabahah (X1) mempunyai hubungan positif berpengaruh namun tidak signifikan terhadap Profitabilitas ROA (Y) pada PT. Bank BNI Syariah i periode 2012-2016

b) Hasil pengujian secara parsial diperoleh nilai Pendapatan Musyarakah bahwa nilai $t_{\text {hitung }}>$ $t_{\text {tabel }}$ sebesar $-0,081<1,720$ dan tingkat signifikansi 0,936 yang berarti nilai tersebut lebih besar dari 0,05. Dari hasil pengujian diatas maka dapat disimpulkan bahwa Ho diterima dan $\mathrm{Ha}$ ditolak, artinya bahwa Pendapatan Musyarakah (X2) secara parsial berpengaruh negatif namun tidak signifikan terhadap Profitabilitas (ROA) pada PT. Bank BNI Syariah periode 2012-2016.

c) Hasil pengujian simultan diperoleh nilai $F_{\text {hitung }}$ sebesar 3,150 dengan tingkat signifikansi 0,69. Dengan mengambil taraf signifikansi $\alpha=$ 0,05 maka $F_{\text {tabel }}$ sebesar 3,59 sehingga nilai $F_{\text {hitung }} 3,150<$ $F_{\text {tabel }} 3,59$ dengan tingkat signifikansi lebih besar dari taraf signifikansi 0,69>0,05 maka dapat disimpulkan bahwa Ho diterima dan Ha ditolak, artinya Pendapatan Murabahah dan Musyarakah secara simultan berpengaruh namun tidak signifikan terhadap Profitabilitas ROA pada PT. Bank BNI Syariah.

\section{DAFTAR PUSTAKA}

Adiwarman A Karim. (2008), Bank islam: Analisis Fiqih dan Keuangan, Ed-3. Jakarta: PT. raja grafindo persada.

Adiwarman A. Karim. (2011), Bank Islam: Analisis fiqih dan keuangan, Ed-4. Jakarta: PT. Raja Grafindo Persada. 
Adrian Sutedi, 2009, Perbankan Syariah,Jakarta: Ghalia Indonesia.

Antonio, Muhamad Syafi'i. 2007, Bank syariah; dari teori ke praktik. Jakarta: Gema insani.

Antonio, Muhammad Syafi'i. (2011), Bank Syariah; Dari Teori ke Praktik. Jakarta: Gema Insani.

Andri Soemitra, 2009, Bank dan Lembaga Keuangan Syariah, Prenada Media, Jakarta.

Anto dan M. Ghofur Wibowo Desember 2012, Faktor Faktor Penentu Tingkat Profitabilitas Bank Umum Syariah Di Indonesia. volume 4 nomor 2 .

Cahyani dan Morita (2009) Perbedaan Pengakuan pendapatan pada bank syariah dan bank konvensional. Dalam Jurnal Ilmiah Kesatuan Nomor 1 Volume 11, Januari 2009

Firdaus, H. Rahmat dan Aryanti. 2009, Manajemen Perkreditan Bank Umum. Bandung: Alfabeta.

Ghozali, Imam. (2013), Aplikasi Analisis Multivariate dengan Program SPSS, Ed-7. Semarang: Badan Penerbit Universitas Diponegoro.

Harahap, Sopyan S. Wiroso dan Muhamad Yusuf. 2010, Akuntansi Perbankan Syariah. Jakarta; LPFE-Usakti.

Harahap, Sofyan Safri 2011. Teori Akuntansi, Edisi Revisi, Cetakan Kelima, PT.Raja Grafindo Perseda, Jakarta
Hanafi, Mamduh M. (2012), Manajemen Keuangan. Yogyakarta: BPFE.

Hery (2016), analisis laporan keuangan, , Jakarta : PT Grasindo

Herman Felani, dan Inta Gina Setiawiani (2016), Pendapatan Mudharabah, Musyarakah dan Murabahah Terhadap Profitabilitas Pada Bank Umum Syariah Periode 2013 - 2015. jurnal Seminar nasional dan $4^{\text {th }}$ call for syariah papper.

http://akuntansikeuangan.com/cashbasis-vs-accrual-basis/

https://akuntansipedia.com/pengakuanpendapatan-psak23/

https://dsnmui.or.id/produk/fatwa/, (diunduh maret 2017)

http://www.ojk.go.id (diunduh maret 2018)

https://www.bnisyariah.co.id (diunduh maret 2018)

http://www.bnisyariah.tripod.com (diunduh maret 2018)

Ismed Wijaya, Yenny Irawan, dan Fauzan Ramadhan Agustus 2016, Pengaruh Pendapatan Murabahah, Mudharabah, dan Musyarakah Terhadap Return On Asset (ROA) pada PT. Bank Syariah Mandiri. Jurnal ekonomi dan bisnis volume 16 nomor 1 .

Kasmir, (2008). Bank dan Lembaga

Keuangan Lainnya.Edisi Revisi. 
PT Rajagrafindo Persada, Jakarta.

Kasmir, (2014), Bank dan Lembaga Keuangan Lainnya. Jakarta: PT. Raja Grafindo persada.

Kieso D.E, Waygandt J.J, Warfield T.D, 2011. Akuntansi Intermediate, Ahli Bahasa : Emil Salim SE, Editor : Yati Sumiharti, Edisi : Kesepuluh. Jilid Satu, Erlangga.Jakarta.

Muhammad. (2014), Manajemen Dana Bank Syariah. Jakarta: PT. Raja Grafindo Persada.

Pandia, Frianto. (2012), Manajemen Dana dan Kesehatan Bank. Jakarta: Rineka Cipta.

Priyatno, Duwi. (2012), Cara Kilat Belajar Analisis Data dengan SPSS 20, Ed-1. Yogyakarta: ANDI.

Sarjono dan julianita. (2011), SPSS Vs LISREL, sebuah pengantar aplikasi untuk riset. Jakarta: Salemba empat.

Sjahdeini (2014) perbankan syariah; produk-produk dan aspek aspek hukumnya,Ed-1. Jakarta: PT Kencana Pranadamedia Group.

Skousen dan Smith Alih Bahasa Alfonsus Sirait. 2010. Akuntansi Intermediate, Edisi Kedua Belas, Penerbit Erlangga, Jakarta.

Sufian Radwan Almanaseer dan. Zaher Abdelfattah AlSlehat (2016) The Impact of Financing Revenues of the Banks on their Profitability: An Empirical Study on Local Jordanian Islamic Banks. European Journal of Business and Management volume 8 nomor 16.

Sugiyono. (2013), Metode Penelitian Pendidikan. Bandung: Alfabeta

Sugiyono. (2014), Metode penelitian kuantitatif, kualitatif, dan $R \& D$, Cetakan ke-12. Bandung: Alfabeta.

Umar, H. (2014), Metode penelitian untuk skripsi dan tesis bisnis, ed2, Cetakan ke-13. Jakarta: Rajawali Pers.

Yusuf wibisono, Mei-Agustus 2009, politik ekonomi undang-undang perbankan syariah- peluang dan tantangan regulasi industri perbankan syariah, dalam jurnal ilmu administrasi dan organisasi volume 16 nomor 2 .

Wangsawidjaja Z. (2012), Pembiayaan Bank Syariah. Jakarta: Gramedia Pustaka Utama.

Wiroso. (2011), Produk Perbankan Syariah, Ed-1, Cetakan Ke-1. Jakarta: LPFE Usakti. 